\title{
Педагогічна селфпроєктна технологія в процесі формування проєктної компетентності майбутніх бакалаврів соціальної роботи
}

\author{
О. В. Купенко
}

Сумський державний університет, м. Суми, Україна
Corresponding author. E-mail: e.v.kupenko@gmail.com

Paper received 10.09.20; Accepted for publication 24.09.20.

https://doi.org/10.31174/SEND-PP2020-236VIII94-10

\begin{abstract}
Анотація. Представлена забезпечуюча педагогічна технологія селфпроєктної діяльності в процесі формування проєктної компетентності майбутніх бакалаврів соціальної роботи. Технологія отримана з використанням методу дослідження в дії. Розглядаються етапи: проєктування, реалізації, аналізу результатів. Передбачається поступове ускладнення пропонованих методів, можливість їх різних комбінацій у технології. Представлені методи аналізу щоденних результатів у реалізації селфпроєкту. Наведені складніші методи селфпроєктної діяльності для застосування після реалізації технології. Обговорюються роль викладача в селфпроєктній діяльності студентів.
\end{abstract}

Ключові слова: майбутні бакалаври сочіальної роботи, педагогічна технологія, селфпроєктна діяльність, проєктна компетентність, метод.

Вступ. Дослідження процесу професійної підготовки як студентоцентрованого, визнання у педагогічній системі студентів як суб'єктів самоуправління визначає необхідність окремої уваги до тієї частини навчального процесу, де ті, хто навчаються, замислюються над баченням розвитку власного «Я» та реалізують це бачення, тобто здійснюють селфпроєктну діяльність.

Особливої уваги селфпроєктна діяльність вимагає у процесі професійної підготовки майбутніх бакалаврів соціальної роботи. Для представників цієї спеціальності селфпроєктна діяльність важлива не лише з точки зору реалізації власної суб'єктної позиції, але і з точки зору підготовки до виконання функції співавторства у селфпроєктній діяльності клієнтів соціальної роботи із розумінням меж своєї професійної відповідальності та перспектив віддання авторства клієнтам.

Короткий огляд публікацій з теми. Нині в інформаційних джерелах наявний доволі значний доробок науковців та практиків щодо самопроєктування та саморозвитку. Виокремлено різні види особистих проєктів: 1) подієвий (як набір нормативних і ненормативних подій, які мають відбутися в житті людини); 2) зміни особистісних характеристик (як складніший ніж подієвий проєкт, що передбачає очікувані людиною зміни особистісних якостей); 3) екзистенціальний (як найскладніша форма проєктування набуття та реалізації життєвих сенсів) [5].

Опрацьовуються механізми запуску селфпроєктної діяльності, самопроєктування. Зазначається, що життєве планування включає підвищення власної обізнаності про себе, власних думок про життя. У свою чергу краща обізнаність про себе забезпечує відповідь на питання про те, що людина хоче зробити із своїм життям [7, с. 16]. Розроблено модель дискурсивного самопроєктування особистості. Підкреслюється важливість авторства людини щодо власних смислових систем на основі інтерпретації та реінтерпретації життєвого досвіду, що передбачає створення проєкту «Я» та постійнейоговідображення, перевизначення, добудовування [4,c.23-29]. Досліджуються наративні та тезаурусні способи самопроєктування [4].

Щодо реалізації селфпроєктів, то увага акцентується на тому, що розвиток особистості відбувається в результаті щоденного досвіду зміни дії [6; 8]; накопичення змін у станах людини в кінцевому підсумку призводить до зміни особистості $[8 ; 9]$.
Констатується, що механізм процесу змін не є простим і що опір змінам $є$ нормальною людською властивістю. Як відповідь дослідниками запропонована, зокрема, модель, що являє собою рекурсивну послідовність повторюваних процесів, в яких короткотерміновий щоденний досвід впливає поступово на довгострокові зміни [9].

Для створення умов максимальної самостійності студентів у селфпроєктній діяльності та нового рівня обізнаності людини про себе в динаміці саморозвитку студентам пропонується щоденна фіксація та аналіз результатів дня за опрацьовуваним комплексом особистісних властивостей [1].

Не зважаючи на наявність значної кількості праць, присвячених самопроєктуванню та саморозвитку, проблемою залишається те, що наявний доробок не знайшов достатнього відображення у реаліях процесу професійної підготовки із врахуванням особливостей тієї чи іншої спеціальності та наявних умов навчального процесу. Зокрема це стосується процесу професійної підготовки майбутніх бакалаврів соціальної роботи.

Мета статті - представлення забезпечуючої педагогічної технології селфпроєктної діяльності в процесі формування проєктної компетентності майбутніх бакалаврів соціальної роботи.

Під ознакою «забезпечуюча» визнання того, що самі студенти роблять вибір займатися чи не займатися селфпроєктною діяльністю, які цілі перед собою поставити та які методи обрати. Однак разом із тим завданням викладача $є$ створення умов, в яких студенти замисляться про селфпроєктну діяльність, іiі цілі та методи, мотивування студентів спробувати попрактикуватися в цьому.

Матеріали та методи. Мета статті реалізується із використанням методів аналізу та синтезу. Теоретичну базу дослідження складають наукові праці з проблеми самопроєктування та саморозвитку, методичну базу - вітчизняний та іноземний інструментальний доробок для селфпроєктної діяльності. Відображені результати педагогічного проєктування, результативність якого перевірена 3 використанням методу дослідження в дії. До експериментальної частини дослідження залучені майбутні бакалаври спеціальності «Соціальна робота».

Результати та їх обговорення. Виходимо 3 того, що майбутні бакалаври соціальної роботи мають навчитися проєктувати та реалізовувати соціальні зміни, але перш за все вони мають навчитися проєктувати власне життя та 
керувати ним, забезпечуючи власний саморозвиток. При цьому аналіз висновків, які студенти отримують опрацьовуючи теорію та практику понять «проєкт» і «проєктна діяльність» як загальних, дозволяє їм більш раціонально зрозуміти процес реалізації людиною становлення власного «Я», забезпечити ефективність і продуктивність цього процесу. 3 іншого боку, робота студента над селфпроєктом покликана додати гуманізму до раціональності освоюваних етапів та методів проєкної діяльності.

По аналогії із визначенням поняття «проєктна діяльність», під селфпроєктною діяльністю розуміємо таку, яка починається зі створення певного образу майбутнього для власного «Я», що забезпечує необхідні переваги порівняно з ситуацією без проєкту, і є можливим за наявних вмінь і ресурсів. Селфпроєктну діяльність розглядаємо у відповідності їі етапів етапам проєктної діяльності як загального: обгрунтування та розроблення селфпроєкту; реалізація селфпроєкту; аналіз отриманих результатів. Однак на відміну від проєктної діяльності як загального, визначеної як такої, що завершується у встановлений час із перетворенням образу бажаного майбутнього на об'єктивну реальність, селфпроєктна діяльність характеризується принциповою незавершеністю, гнучкістю та здатністю до перевизначення у змінюваності соціокультурних реалій та особистісних станів.

У ході проєктування забезпечуючої технології селфпроєктної діяльності в процесі формування проєктної компетентності майбутніх бакалаврів соціальної роботи виходимо з того, що, з одного боку, селфпроєктна діяльність - це діяльність максимальної свободи вибору студентів, однак, з іншого боку, не всі студенти готові до здійснення такого вибору, не замислювалися раніше над подібним колом питань, їм важно приймати рішення, вони потребують на початкових етапах підтримки. Тому ідеєю проєктування стало поступове ускладнення пропонованих студентам до використання методів селфпроєктної діяльності. Далі наведемо змістовне наповнення компонентів забезпечуючої педагогічної технології селфпроєктної діяльності у процесі формування проєктної компетентності майбутніх бакалаврів соціальної роботи, отримане шляхом аналізу та синтезу, педагогічного проєктування, а також із використанням дослідження в дії отримано таке.

Мета технології: надати досвід використання методів і засобів селфпроєктної діяльності, узагальнити цей досвід із точки зору перспектив її продовження студентами, а також перспектив надання майбутнім бакалаврам соціальної роботи орієнтовної основи для створення ними в перспективі умов для селфпроєктної діяльності клієнтів соціальної роботи.

Вихідний стан технології: ність досвіду самопроєктування у більшості студентів (що знайшло своє підтвердження в емпіричній частині дослідження).

Етапи технології (з урахуванням ускладнення методів, пропонованих до опрацювання студентам):

- проєктування:

- методи «Самооцінка якості життя», «Карта бажань», «Лінія життя»;

- метод «Я-книга»;

- дискурсивне (наративне та тезаурусне) селфпроєктування;

- реалізація:

- застосуванням рекурсивної послідовності TESSERA;
- самоаналіз щоденних процесів і результатів;

- щотижневе обговорення прогресу;

- аналіз результатів:

- самоаналіз процесу і результату за підсумка селфпроєкту;

- обговорення в групі;

- обговорення перспектив щодо подальшої селфпроєктної діяльності студентів (метод «Сходини»), а також щодо перспектив співавторства у селфпроєктній діяльності клієнтів соціальної роботи (метод дебатів).

Оцінка результату здійснюється за продемонстрованими студентами знаннями та досвідом, професійною творчістю, самостійністю, готовністю до сприяння реалізації прав інших людей; діями самопроєктування.

Корегування передбачене із використанням елементів наставництва та коучингу.

Деталізуємо етапи технології.

На першому етапі селфпроєктної діяльності (етапі проєктування) виходимо $з$ того, що життєве планування включає підвищення власної обізнаності про себе, власних думок про життя. Краща обізнаність про себе забезпечує відповідь на питання про те, що людина хоче зробити із своїм життям [7, с. 16]. Передбачається три варіанти аналізу себе для подальшого самопроєктування, що зростають за складністю. Найбільш доступний та формалізований варіант - використання методів «Самооцінка якості життя», «Карта бажань», «Лінія життя» [3, с.237247]. Проміжним за складністю варіантом є методика «Якнига» [2], що передбачає написання авторського тесту, але задає для цього вужчі рамки, ніж наступний дискурсивний варіант самопроєктування. Дискурсивний варіант самопроєктування в свою чергу реалізується як наратив (створення власної ідеальної історії) або як тезаурус (створення ідеальної особистісно неповторної картини світу) [4, с. 22]. Комплект названих методів надає студентові можливість вибору способу, яким чином досліджувати власне «Я» та здійснювати самопроєктування. Кожен із цих методів не передбачає будь-яких ключів для підсумовування результатів. Їх завдання в іншому: надати людині достатньо широкий матеріал для визначення того, які б власні властивості вона хотіла змінити які нові риси набути. Також важливо підкреслити, що пропоновані методи задають можливість варіативності навчального процесу. Підготовленіші студенти можуть швидше опрацювати більш формалізовані методики та перейти до дискурсивного проєктування. Роблячи свої тезауруси та наративи публічними в соціальній мережі (в рамках закритої групи чи у себе на сторінці), в тому числі представляючи їх у відеоформаті, більш підготовлені для такої роботи студенти дають приклад іншим, навіть «заражають» інших енергією до саморозвитку.

Під час реалізації студентських селфпроєктів особливого значення набуває короткотерміновий щоденний досвід (оцінений за допомогою самоаналізу), що впливає поступово на довгострокові зміни. Абревіатура TESSERA розшифровується як Triggering situations (тригерна ситуація), Ехресtancy (очікування), States/State expressions (стани/вираження станів), Reactions (реакціï) [9]. Виходячи із знання про зв'язок короткотермінового досвіду із довгостроковою зміною на базі рекурсивних послідовностей TESSERA пропонується таке формулювання завдання студентам щодо селфпроєктної діяльності: 
- за підсумками самодіагностики визначте для себе особистісну властивість, яку хотіли б змінити (позбутися чи набути). Для цієї властивості доберіть короткотермінову дію, пов'язану із нею. Обрану короткотермінову дію виконуйте 30 днів поспіль. Задайте при цьому для себе тригер, який буде нагадувати про необхідність виконання дії (наприклад, налаштуйте будильник на мобільному пристрої на найближчі 30 днів на зручний час для виконання діï);

- фіксуйте свої стани та реакції у щоденнику протягом 30 днів;

- підготуйте заключну презентацію за структурою: 1) щоденний тригер, очікування, стан/вираження стану, реакція протягом 30 днів; 2) підсумок досягнутих результатів і труднощів за 30 днів; 3) висновки щодо співавторства фахівця соціальної роботи у селфпроєктній діяльності клієнтів;

- зробіть презентацію на студентській загал в академічній групі.

В якості ілюстрації до такої постановки завдання наведемо приклади тематики успішно реалізованих у ході експериментальної частини дослідження студентських селфпроєктів: формування звички відмови від вжитку пластикової упаковки; формування звички щоденного читання; формування звички щоденних фізичних вправ; утримання від зайвих покупок; вдосконалення англійської; планування часу; розвиток стресостійкості; контроль за гнівом.

Окремої уваги в завданні щодо реалізації селфпроєкту вимагає частина рефлексії та ведення щоденника. При чому важливим вбачається надати студенту вибір форми фіксації та аналізу щоденних результатів. В якості першого варіанту форми щоденної фіксації у ході реалізації селфпроєкту можуть бути використані структури послідовності TESSERA [9]. Другий варіант - щоденна фіксація за набором контрольних питань по особистісним властивостям, що розвиваються. Питання пропонується ставити у структурі «Чи зробив(ла) я все можливе, щоб ...».
Такі запитання спрямовують на оцінку докладених зусиль, випереджаючи своїм розумінням ситуації як такої, коли за кілька днів більш чи менш докладені зусилля по окремим діям накопичуються у помітно кращий чи гірший результат щодо розвитку особистісних властивостей [1]. В якості третього варіанту щоденної фіксації та аналізу уваги заслуговують тематичні щоденники, наприклад, «Щоденник з ненасильницької комунікації», виданий у рамках проєкту «Розбудова заради майбутнього: цілісний підхід до зміцнення громадянського суспільства на Донбасі», за методикою С. Рамбали. Для набуття особистісної властивості ненасильницької комунікації п’ять вправ у щоденнику згруповані за тижнями для послідовного виконання дій: базова формула ненасильницької комунікації (виконання двічі на тиждень), самовдячність (тричі на день), вдячність іншим (щодня), самоемпатія (щодня), реакція на критику (щодня). На кожен день запропоновані відповідні деталізовані форми виконання дій та рефлексії.

Різні варіанти самопроєктування та щоденної фіксації і аналізу результатів у ході реалізації селфпроєкту пропонуються для того, щоб надати студентам досвід використання методів селфпроєктної діяльності, залишивши студентам можливості для вибору, а також запросивши їх до подальшого саморозвитку вже за межами навчального процесу, в колі відповідальності самих студентів.

Як розширений варіант подальшої селфпроєктної діяльності студентам презентується метод «Сходи» [6]. Метод «Сходи» передбачає виокремлення понять «мрія», «ціль», «крок». Метод виходить із того, що лише мрій недостатньо, адже вони не забезпечать проходження щоденних випробувань. Потрібно зосередитися і знайти перший правильний крок, вклавши всю енергію, щоб його зробити. Далі виділити час, щоб осмислити зроблене та отриманий результат. Потім зробити ще один крок. 3 кожним кроком зростає впевненість і підвищується вірогідність, що вже не відступити. Це сила «сходів» [6].

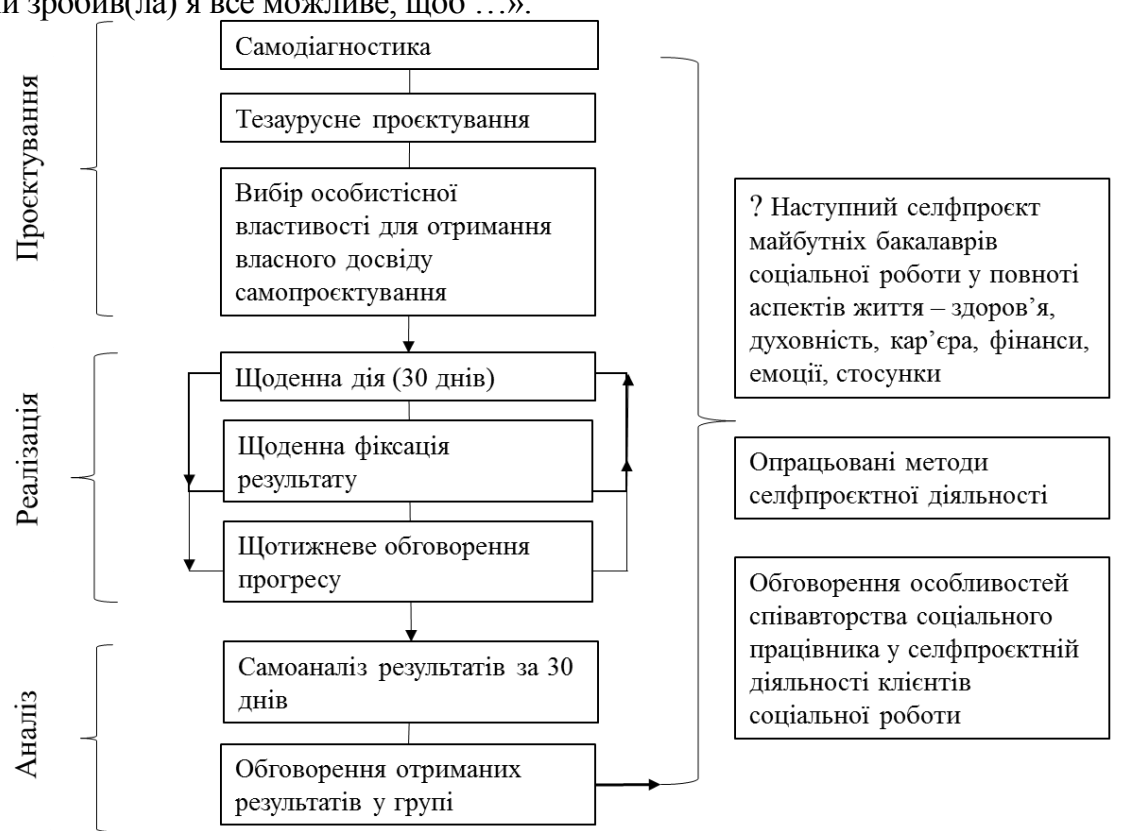

Рисунок 1. - Етапи забезпечуючої технології селфпроєктної діяльності в процесі формування проєктної компетентності майбутніх бакалаврів соціальної роботи

Метод «Сходи» у відповідності до технології, що представляється у цій статті, залишається за межами регламентів навчальних дисциплін програми бакалавріату
«Соціальна робота». Однак обговорення цього методу зі студентами $є$ підсумком досвіду застосування рекурсивної послідовності TESSERA як послідовності щоденних 
кроків для досягнення за один місяць певної цілі. Тобто (наслідуючи тезу про те, що гарний проєкт - це той, після завершення якого суб'єкт розуміє наступний крок) вдало реалізованим квазіселфпроєктом є той, після якого студенти розуміють, яким чином реалізовувати наступні й які саме, мають бажання це зробити.

Таким чином пропонується реалізувати забезпечуючу педагогічну технологію селфпроєктної діяльності в ускладненні та варіюванні методів, з яких вона конструюється. Етапи технології в узагальненому вигляді представлені на рисунку 1.

Результати та обговорення. Забезпечуючу педагогічну технологію селфпроєктної діяльності в процесі формування проєктної компетентності майбутніх бакалаврів соціальної роботи пропонуємо розглядати у ії взаємному доповненні з забезпечуючою педагогічною технологією наставництва. В такому контексті маємо зауважити. 3 одного боку, селфпроєктна діяльність - це діяльність максимальної свободи вибору студентів, однак, 3 іншого боку, не всі студенти володіють достатнім рівнем самоуправління для цього. Для забезпечення відповідної варіативності навчального процесу завдання ставиться з максимальним ступенем свободи студентів у виборі методів і цілей селфпроєктної діяльності, але за потреби педагогнаставник визначає доцільну інтенсивність втручання в процес. Використання формулювання «завдання ставиться» щодо завдань селфпроєктної діяльності робить їі дещо умовною (квазіселфпроєктною) у крайньому разі для окремих студентів. Однак вбачаємо такий підхід продуктивним, за умови відкриття студентам подальших перспектив. Розуміємо участь викладача у селфпроєктній діяльності студентів як питання дискусії. Але розуміємо і потребу у підтримці з боку певної частини студентства. При цьому важливу роль віддаємо прикладу тих студентів, кому вдалося досягти власних результатів у селфпроєктній діяльності. Особливо важливим вбачається взаємодія таких студентів старших курсів із студентами молодших курсів.

Висновки. Селфпроєктна діяльність вбачається важливою складовою у процесі професійної підготовки майбутніх бакалаврів соціальної роботи. Емпіричним шляхом із використанням методу дослідження в дії встановлено, що пропонована забезпечуюча педагогічна технологія дозволяє студентам набути перший досвід у селфпроєтній діяльності, а також підсилює результати щодо формування проєктної компетентності, готовності працювати 3 клієнтами соціальної роботи у найближчому майбутньому. Разом 3 тим доступний на сьогоднішній день інструментарій в різних вітчизняних та іноземним джерелах щодо селфпроєктної діяльності дозволяє робити різні комбінації методів, проєктувати технології і відповідним чином спрямовувати зусилля на різні акценти у компетентностях майбутніх бакалаврів соціальної роботи. Важливо підкреслити, що в таких технологіях вбачається доцільним давати студентам широкі можливості вибору щодо цілі селфпроєктної діяльності та методів їі реалізації.

\section{ЛІТЕРАТУРА}

1. Голдсмит, М., Рейтер, М. (2016) Тригzеры. Формируй привычки - закаляй характер. Москва : Манн, Иванов и Фербер.

2. Гущина, Т. Н. (2008) Игровые технологии по формированию соииальных навыков у подростков: Практическое пособие. Москва : АРКТИ.

3. Кияниця, 3. П., Петрочко, Ж. В. (2017) Сочіальна робота 3 вразливими сім'ями та дітьми : посіб. у 2-х ч.; Ч. І. Сучасні орієнтири та ключові технології. Київ : ОБНОВА КОМПАНІ.

4. Чепелєва, Н. В., Смульсон, М. Л., Рудницька, С.Ю., Зазимко, О.В. (2019) Дискурсивні технології самопроектування особистості: монографія. Київ : Інститут психології імені Г. С. Костюка НАПН України.

5. Чуева, Н.А. (2013) Возростная динамика жизненного проекти-

рования. Известия Тульского государственного университета. Гуманитарные науки, 3, 284-294.

6. Янг, Ш. (2019) Привычки на всю жизнь. Научный подход к формированию устойчивых привычек. Москва: Манн, Иванов и Фербер.

7. Glint, H. (2006) “What Do You Want To Do With Your Life?” Your Life Plan To Find Your Answer. Oslo.

8. Quintus, M. (2019) Personality Development in Adulthood: The Role of Life Transitions, Goals to Change Personality, and Momentary Processes: Inauguraldissertation zur Erlangung des Akademischen Grades des Doctor philosophiae (Dr. phil.). Mainz.

9. Wrzus, C., Roberts, B. (2017) Processes of Personality Development in Adulthood: The TESSERA Framework. Personality and Social Psychology Review, 21, 253-277.

\section{REFERENCES}

1. Goldsmith, M., Reuters, M. (2016) Triggers. Form the habits temper the character. Moscow: Mann, Ivanov and Ferber.

2. Gushchina, T. N. (2008) Game technologies for the formation of social skills in adolescents: A Practical Guide. Moscow: ARKTI.

3. Kiyanitsa, Z. P., Petrochko, Zh. V. (2017) Social work with vulnerable families and children: a manual in 2 parts; Modern landmarks and key technologies. Kyiv: COMPANY RENEWAL.

4. Chepeleva, N. V., Smulson, M. L., Rudnytska, S. Y., Zazymko, O. V. (2019) Discursive technologies of personality self-design:

a monograph. Kyiv: Kostyuk Institute of Psychology of the National Academy of Pedagogical Sciences of Ukraine.

5. Chueva, N. A. (2013) Existential vital design as fastigium of vital designing. Izvestiya of the Tula State University. Humanitarian sciences, 3, 284-294.

6. Young, S. (2019) Habits for life. A scientific approach to building sustainable habits. Moscow : Mann, Ivanov and Ferber.

\section{Pedagogical self-project technology in the process of formation the project competence of future bachelors of social work}

O. V. Kupenko

Abstract. The providing pedagogical technology of self-project activity in the process of formation the project competence of future bachelors of social work is presented. The technology is obtained as a result of pedagogical project activity and using the research method in action. Future bachelors of specialty "Social work" were involved in the experimental part of the research. Among the stages of technology are considered design, implementation, analysis of results. At the same time, the gradual complication of the methods offered to students and the possibility of their various combinations during the implementation of the technology is envisaged. Particular attention is paid to the methods of recording and analyzing daily results during the implementation of the self-project. More complex methods of self-project activity for application after implementation the technology are presented. The role of the teacher in the process of self-project activity of students is discussed.

Keywords: bachelor of social work, pedagogical technology, self-project activity, project competence, method. 